\title{
Fusarium mycotoxins: a review of global implications for animal health, welfare and productivity
}

\author{
J.P.F. D’Mello*, C.M. Placinta, A.M.C. Macdonald \\ The Scottish Agricultural College, Department of Biotechnology, West Mains Road, Edinburgh EH9 3JG, UK
}

Received 12 January 1999; received in revised form 20 April 1999; accepted 18 May 1999

\begin{abstract}
Trichothecenes, zearalenone (ZEN) and fumonisins are the major Fusarium mycotoxins occurring on a worldwide basis in cereal grains, animal feeds and forages. Other important Fusarium mycotoxins include moniliformin and fusaric acid. Spontaneous outbreaks of Fusarium mycotoxicoses have been recorded in Europe, Asia, New Zealand and South America and, in addition, chronic exposure occurs on a regular and more widespread scale. The metabolism and adverse effects of the Fusarium mycotoxins are considered in this review with particular reference to recent data on specific and proposed syndromes and to interactions among co-occurring mycotoxins. Within the trichothecene group, deoxynivalenol (DON) is associated with emesis, feed refusal and depressed feed intake in pigs, while T-2 toxin and diacetoxyscirpenol (DAS) are now clearly linked with oral lesions in poultry. The gut microflora of farm livestock are able to transform DON to a de-epoxy derivative. In contrast, the ovine metabolism of ZEN results in the production of five metabolites and relatively high levels of these forms may be excreted in the urine as glucuronides. There is now undisputed evidence that ZEN and its metabolites possess estrogenic activity in pigs, cattle and sheep, but T-2 toxin has also been implicated in reproductive disorders in farm livestock. Fumonisins are positively linked with pulmonary edema in pigs, leukoencephalomalacia in equines and with deranged sphingolipid metabolism in these animals. Fusarium mycotoxins have also been provisionally implicated in ovine ill-thrift, acute mortality of poultry and in duodenitis/proximal jejunitis of horses. Several Fusarium mycotoxins may co-occur in a particular feed ingredient or in compound feedingstuffs. In general, combinations of Fusarium
\end{abstract}

\footnotetext{
* Corresponding author Tel.: +44-131-535-4144; fax: +44-131-667-2601

E-mail address: f.dmello@ed.sac.ac.uk (J.P.F. D’Mello)

Abbreviations: DON, deoxynivalenol; 3-ADON, 3-acetyl DON; NIV, nivalenol; DAS, diacetoxyscirpenol; ZEN, zearalenone; $\mathrm{FB}_{1}, \mathrm{FB}_{2}, \mathrm{FB}_{3}$, fumonisins $\mathrm{B}_{1}, \mathrm{~B}_{2}, \mathrm{~B}_{3}$; MON, moniliformin; OA, ochratoxin $\mathrm{A} ; \mathrm{LD}_{50}$, median lethal dose; LH, luteinizing hormone; Sa, sphinganine; So, sphingosine; ELEM, equine leukoencephalomalacia; DPJ, duodenitis/proximal jejunitis; PPE, porcine pulmonary edema
} 
mycotoxins result in additive effects, but synergistic and/or potentiating interactions have been observed and are of greater concern in livestock health and productivity. Synergistic effects have been reported between DON and fusaric acid; DON and fumonisin $\mathrm{B}_{1}\left(\mathrm{FB}_{1}\right)$; and DAS and the Aspergillus-derived aflatoxins. Limited evidence of potentiation between $\mathrm{FB}_{1}$ and $\mathrm{DON}$ or $\mathrm{T}-2$ toxin has also emerged recently. Additive and synergistic effects between known and unidentified mycotoxins may account for enhanced adverse effects observed on feeding Fusarium-contaminated diets. The potential for transmission of DON into eggs and of ZEN into porcine kidney and liver has been demonstrated. However, lactational carry-over of $\mathrm{FB}_{1}$ appears not to occur, at least in cows and sows. It is concluded that livestock health, welfare and productivity may be severely compromised by consumption of DON, T-2 toxin, DAS, ZEN and fumonisins and by interactions among these mycotoxins. Safety of some animal products may also be at risk. Furthermore, in view of the limited options available for remediation, it is concluded that exploitation of crops resistant to Fusarium infection offers the most viable strategy for reducing mycotoxin contamination of grain and animal feed. (C) 1999 Elsevier Science B.V. All rights reserved.

Keywords: Fusarium sp., Trichothecenes; Zearalenone; Fumonisins; Livestock; Metabolism; Syndromes; Interactions; Residues; Decontamination; Amelioration

\section{Introduction}

There is now compelling evidence implicating the Fusarium mycotoxins in livestock disorders in different parts of the world. Furthermore, the risk of continuing exposure has not diminished in spite of enhanced awareness of the debilitating effects of these mycotoxins. Thus, Placinta et al. (1999) concluded that on a global scale, cereal grains and animal feed may be subject to multiple contamination with trichothecenes, zearalenone and fumonisins, the major mycotoxins of Fusarium fungi. Contamination of feed grains is inevitable since many toxigenic species of Fusarium are also common phytopathogens, producing cereal crop diseases which are difficult to control. The unexpected lack of efficacy of pesticides in general and fungicides in particular to control cereal diseases and consequent mycotoxin contamination of grain has been the focus of a major review (D'Mello et al., 1998). Among the trichothecenes, deoxynivalenol (DON) and nivalenol (NIV) co-occur regularly throughout the world, with unacceptably high values in cereal grains in Poland, Germany, Japan, New Zealand, and the Americas (Placinta et al., 1999). Other co-occurring trichothecenes in grain and feeds included 3acetyl DON (3-ADON), diacetoxyscirpenol (DAS), T-2 toxin and HT-2 toxin. Concentrations of zearalenone (ZEN) are generally low, but above-average values have been reported for cereal grains or animal feed in Japan, New Zealand and South Africa. Fumonisin $\mathrm{B}_{1}\left(\mathrm{FB}_{1}\right)$ is a major contaminant of maize and animal feed in many tropical countries including China, Thailand and South Africa, whereas in Argentinian maize $\mathrm{FB}_{2}$ was the predominant form of the mycotoxin in one study.

The co-occurrence of individual trichothecenes in cereal grains and animal feed is serious enough in that it is not possible yet to quantify the extent of any resulting interactions on animal health and performance. However, of greater potential significance are widespread reports of co-contamination of grain and feeds with trichothecenes, fumonisins and the Aspergillus-derived aflatoxins (Placinta et al., 1999). 
It is clear that chronic intake of Fusarium and indeed other mycotoxins by farm livestock is inevitable and there are numerous cases of suspected mycotoxicoses on a worldwide basis. In addition, specific conditions have been positively identified and there is now sufficient data to propose further syndromes arising from other Fusarium mycotoxins such as fusaric acid and moniliformin (MON). Both aspects are reviewed in this paper to reflect the increased impetus currently being accorded to the toxicity of a wide range of these mycotoxins. Furthermore, new data have been published on the metabolism of certain Fusarium mycotoxins and it is opportune that these aspects are also considered in this paper. Although reviews are available (Diekman and Green, 1992; Etienne and Dourmad, 1994; Prelusky et al., 1994a), current evidence questions the validity of some of the original conclusions. New aspects of the aetiology of specific syndromes and the nature of interactions among Fusarium mycotoxins have also recently emerged. In addition, the toxicological implications of co-occurrence of Fusarium mycotoxins with those from Aspergillus fungi deserve attention to enable a proper assessment of risk in animal production. Placinta et al. (1999) examined the evidence of global contamination of grain and animal feed with Fusarium mycotoxins but the toxicological aspects were alluded to in a perfunctory manner without critical appraisal of published data. Furthermore, the question of synergism among co-occuring mycotoxins remained largely unexplored. Similarly, D’Mello et al. (1997) presented a superficial account of the toxicology of Fusarium mycotoxins focusing on structural diversity and biological activity and on interactions involving fusaric acid. The general reviews of Flannigan (1991) and of D'Mello and Macdonald (1997, 1998) covered wide-ranging aspects including factors affecting mycotoxin production, their role as disease elicitors in plants and risk assessment in human health. Specific updated aspects concerning the effects of Fusarium mycotoxins in farm animals were not considered in the aforementioned papers in the detail justified by recent developments. There is thus a compelling case for a critical and comprehensive review of Fusarium mycotoxicology that embodies important issues such as metabolism, syndromes, interactions, residues, tolerance limits and amelioration.

\section{Metabolism}

Metabolism of mycotoxins by animals may affect the manifestation of adverse effects. There may also be additional implications for carcass and milk quality if extensive transformation occurs within the digestive tract or within the tissues of animals.

The microbial transformation of DON in the gut of animals is well documented. A recent investigation attempted to elucidate the site at which this activity was greatest in pigs and the nature and relative toxicity of the metabolites formed (Kollarczik et al., 1994). Using an in vitro system it was determined that, as might be expected, microbial transformation of DON was highest in the caecum, colon and rectum. The only metabolite detected was de-epoxy-DON, a product also formed in the hind gut of other animals including cattle. Furthermore, it was shown that this transformation of DON was accompanied by a significant loss of cytotoxicity to pig kidney cells (Kollarczik et al., 1994). 
The ovine metabolism of ZEN has been proposed to include the synthesis of at least five metabolites including zearalanone, $\alpha$-zearalenol, $\beta$-zearalenol, $\alpha$-zearalanol and $\beta$-zearalanol (Miles et al., 1996). High levels of some of these forms may be excreted in the urine as glucuronides by grazing sheep. Passage through the rumen is not necessary to promote these transformations. It should be noted that $\alpha$-zearalanol has been marketed as a growth promoter with the name zeranol. Its use has been banned in the European Union (EU), but monitoring is continuing in countries where zeranol is permitted in order to comply with requirements for carcasses imported into the EU. However, complications have arisen due to the occurrence of zeranol in the urine of untreated pasture-fed ruminants and equines. The studies of Miles et al. (1996) indicate that urinary zeranol may arise in such animals as a result of metabolism of ZEN and related compounds present naturally in pastures infected with Fusarium species.

The adverse effects of ZEN will be partly determined by the processes of elimination. In pigs, as in sheep, ZEN is conjugated with glucuronic acid and in addition may be metabolised to $\alpha$-zearalenol. However, the studies of Biehl et al. (1993) with sexually immature pigs indicate that biliary excretion and enterohepatic cycling are important processes affecting the fate of ZEN. It was suggested that the glucuronide of ZEN was substantially excreted in bile to be re-absorbed and metabolised further by intestinal mucosal cells, ultimately entering the liver and the systemic circulation via the portal blood supply. It was proposed that this entero-hepatic cycling has the effect of prolonging the retention of ZEN and its derivatives in the circulatory system, retarding elimination and enhancing the duration of adverse effects. It was also suggested that the reduction of ZEN to $\alpha$-zearalenol occurred most actively in the intestinal mucosa (Biehl et al., 1993).

\section{Toxicology and syndromes}

In common with other physiologically active compounds, the Fusarium mycotoxins are capable of inducing both acute and chronic effects. The effects observed are often related to dose levels and duration of exposure.

Although acute and chronic effects in farm livestock are readily demonstrated under experimental conditions, similar manifestations have been reported in natural outbreaks of Fusarium mycotoxicoses in Europe, Asia, New Zealand and South America (Fazekas and Bajmocy, 1996; Prathapkumar et al., 1997; Kramer et al., 1997; Galhardo et al., 1997). Chronic exposure of farm animals to DON is a continuing hazard in Canada, the USA and continental Europe. In Japan, several cases of mycotoxicoses in animals have been attributed to consumption of cereals contaminated with DON and NIV (Yoshizawa, 1991). A number of specific syndromes in farm livestock have now been positively linked with exposure to certain trichothecenes, ZEN, and fumonisins. These include feed refusal, emesis and anorexia; oral and gastro-intestinal lesions; ill-thrift; reproductive dysfunction; equine leukoencephalomalacia; and porcine pulmonary edema. In addition, Duodenitis/ proximal jejunitis and acute mortality syndrome have tentatively been linked with particular Fusarium mycotoxins. 
Table 1

Adverse effects of individual trichothecenes in pigs

\begin{tabular}{|c|c|c|}
\hline Trichothecene & Effects & Data source \\
\hline DON & Emesis and feed refusal & $\begin{array}{l}\text { Review by Diekman } \\
\text { and Green (1992) }\end{array}$ \\
\hline DON & Decreased feed intake, growth and feed efficiency & Bergsjo et al. (1992) \\
\hline DON & Reduced feed intake and growth; stomach lesions & Friend et al. (1992) \\
\hline DON & $\begin{array}{l}\text { Depressed feed intake, growth, feed efficiency and carcass weight; } \\
\text { reduced blood levels of total protein, albumin, } \mathrm{Ca} \text { and } \mathrm{P}\end{array}$ & Bergsjo et al. (1993) \\
\hline DON & Reduced feed intake and growth; recovery in pigs fed pure DON & Prelusky et al. (1994b) \\
\hline DON & $\begin{array}{l}\text { Immediate reductions in feed intake and growth followed by } \\
\text { partial dose-dependent recovery }\end{array}$ & Trenholm et al. (1994) \\
\hline DON & $\begin{array}{l}\text { Reduced feed intake and growth; increased corrugation of mucosa } \\
\text { in stomach; transient decrease in serum protein levels }\end{array}$ & Rotter et al. (1995) \\
\hline DON & Renal lesions & Harvey et al. (1996) \\
\hline $\mathrm{DON}$ & $\begin{array}{l}\text { Dose-dependent reduction in secondary antibody response to } \\
\text { tetanus toxoid }\end{array}$ & Overnes et al. (1997) \\
\hline NIV & $\begin{array}{l}\text { Profound reduction in feed intake at high doses; diets also } \\
\text { contaminated with ZEN }\end{array}$ & $\begin{array}{l}\text { Williams and Blaney } \\
\text { (1994) }\end{array}$ \\
\hline NIV & Increased time to consume feed & Hedman et al. (1997) \\
\hline $\mathrm{T}-2$ toxin & Reduced feed intake & Friend et al. (1992) \\
\hline $\mathrm{T}-2$ toxin & $\begin{array}{l}\text { Dermatitis of snout, nose and buccal commissures; feed refusal; } \\
\text { depressed feed intake, growth, and blood glucose levels; increased } \\
\text { blood levels of inorganic } \mathrm{P} \text { and } \mathrm{Mg}\end{array}$ & Rafai et al. (1995a) \\
\hline $\mathrm{T}-2$ toxin & $\begin{array}{l}\text { Decreased red blood cell count, corpuscular volume and } \\
\text { hemoglobin concentration; reduced leucocyte count, proportion } \\
\text { of T lymphocytes, antibody formation and blastogenic } \\
\text { transformation of lymphocytes }\end{array}$ & Rafai et al. (1995b) \\
\hline
\end{tabular}

\subsection{Trichothecenes}

In acute tests with trichothecenes, type A members such as DAS and T-2 toxin have been found to be more toxic than type B components such as DON and NIV (Leeson et al., 1995). However, the effects and syndromes arising from chronic intake of these mycotoxins are likely to be more important in practical situations (Tables 1 and 2; Fig. 1). In addition, a feature of at least two trichothecenes (DON and T-2 toxin) is their ability to impair immunocompetence, a property which may well be associated with other mycotoxins in this group (Kubena et al., 1997a; Vanyi et al., 1994b). Furthermore, in sows, T-2 toxin may cause infertility, and after parenteral administration during the last trimester of gestation, is able to precipitate abortion within $48 \mathrm{~h}$ (Weaver et al., 1986). Its role as an endocrine disrupter is now beginning to emerge (Table 2).

\subsubsection{Feed refusal, emesis and anorexia}

Earlier studies with pigs indicated that DON was a potent feed intake inhibitor and emetic factor. These effects were appropriately represented by the alternative term for this mycotoxin, namely 'vomitoxin'. However, recent studies (Table 1) have only confirmed the anorectic effects. In quantitative terms marked effects of DON on feed intake 
Table 2

Adverse effects of individual trichothecenes in non-porcine livestock

\begin{tabular}{|c|c|c|c|}
\hline Trichothecene & Animal species/type & Effects & Data source \\
\hline DON & Broiler chickens & $\begin{array}{l}\text { Increased relative weights of gizzard, } \\
\text { bursa of Fabricus and heart }\end{array}$ & Kubena et al. (1997a) \\
\hline DON & Laying hens & $\begin{array}{l}\text { Transmission to eggs following oral } \\
\text { administration }\end{array}$ & Prelusky et al. (1987) \\
\hline DON & Mink & Preference for non-contaminated feed & Gibson et al. (1993) \\
\hline 3-ADON & Lambs & Depressed feed intake & Brewer et al. (1996) \\
\hline NIV & Broiler chickens & $\begin{array}{l}\text { Reduced feed consumption and weight } \\
\text { gain; gizzard erosions; reduced relative } \\
\text { liver weight }\end{array}$ & Hedman et al. (1995) \\
\hline $\mathrm{T}-2$ toxin & Virgin female rabbits & $\begin{array}{l}\text { Impaired ovarian function; low plasma } \\
\text { progesterone levels }\end{array}$ & Fekete et al. (1992) \\
\hline $\mathrm{T}-2$ toxin & Turkey poults & Reduced bodyweight gain; oral lesions & Kubena et al. (1995) \\
\hline $\mathrm{T}-2$ toxin & Broiler chickens & Reduced bodyweight gain; oral lesions & Kubena et al. (1997a) \\
\hline $\mathrm{T}-2$ toxin & Ducklings & $\begin{array}{l}\text { Reduced bodyweight and weights of } \\
\text { thymus, spleen and bursa of Fabricii; } \\
\text { oral and oesophageal ulcerations }\end{array}$ & Neiger et al. (1994) \\
\hline $\mathrm{T}-2$ toxin & Geese & $\begin{array}{l}\text { Decreased egg yield and hatchability; } \\
\text { mortality }\end{array}$ & Vanyi et al. (1994a) \\
\hline $\mathrm{T}-2$ toxin & Geese & $\begin{array}{l}\text { Dose-dependent cessation of follicle } \\
\text { maturation in ovaries; follicle degeneration; } \\
\text { involution of oviduct; lymphocyte depletion; } \\
\text { lesions in adrenal and thyroid glands }\end{array}$ & Vanyi et al. (1994b) \\
\hline DAS & Broiler chickens & $\begin{array}{l}\text { Reduced bodyweight; dose-related } \\
\text { mouth lesions }\end{array}$ & $\begin{array}{l}\text { Ademoyero and } \\
\text { Hamilton (1991) }\end{array}$ \\
\hline DAS & Turkey poults & $\begin{array}{l}\text { Reduced feed intake, weight gain and } \\
\text { feed efficiency; oral lesions }\end{array}$ & Kubena et al. (1997b) \\
\hline DAS & Cattle & $\begin{array}{l}\text { Anorexia; gastro-intestinal lesions; } \\
\text { diarrhoea; reduced milk production }\end{array}$ & Galhardo et al. (1997) \\
\hline
\end{tabular}

inhibition have been observed particularly in the range $6-15 \mathrm{mg} / \mathrm{kg}$ diet (Fig. 1). At a level of $15 \mathrm{mg} / \mathrm{kg}$, feed intake was only 0.38 of control values. Even at the higher levels of DON, however, emesis was not observed (Trenholm et al., 1994). A particular feature of the appetite depression is that although the effect can be immediate, varying degrees of recovery over time have been reported, without withdrawal of DON from the feed. Thus, Trenholm et al. (1994) noted partial, dose-dependent, adaptation to DON-contaminated diets, the effects being reflected in proportionate reductions in weight gain. On the other hand, Prelusky et al. (1994b) observed feed intake depression for the initial two days of feeding the contaminated diet followed by sufficient compensation thereafter to permit feed intakes and growth rates equivalent to those in control pigs. Despite these differing responses a distinct dose-related effect of dietary DON on feed intake in pigs is still evident (Fig. 1) even in the long-term (Trenholm et al., 1994). Pair-feeding studies with pigs indicate that at the lower dose ranges, the effects of DON on growth may be explained entirely by the effects on voluntary feed intake (Rotter et al., 1995). However, Prelusky (1997) concluded that at relatively high dietary concentrations of DON (above $9 \mathrm{mg} / \mathrm{kg}$ ), the deleterious effects on weight gain may not be fully explained by the 


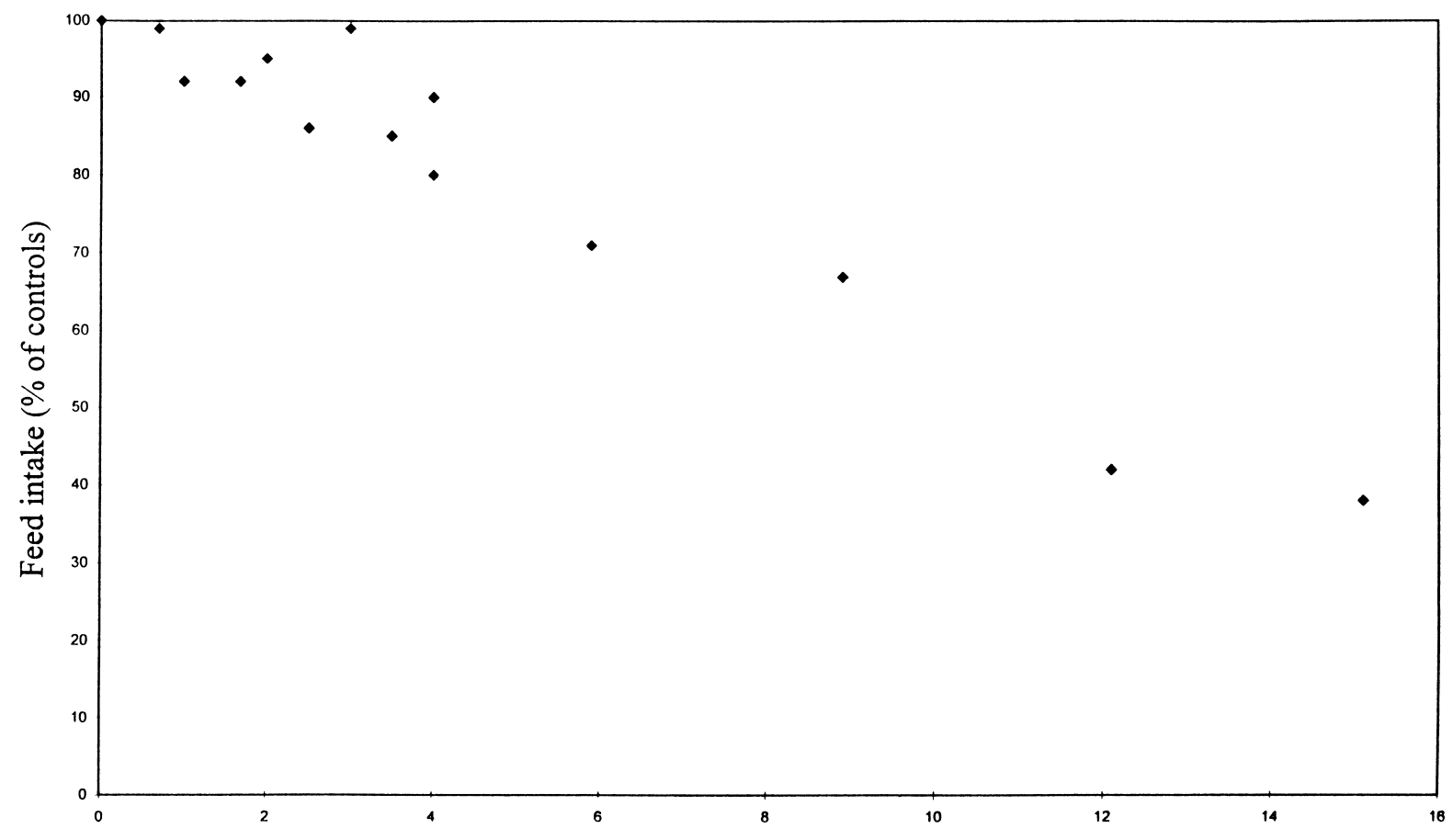

Dietary DON levels $(\mathrm{mg} / \mathrm{kg})$

Fig. 1. Effects of dietary deoxynivalenol (DON) levels on voluntary feed intake in pigs. Data selected from Bergsjo et al. (1992), Friend et al. (1992), Bergsjo et al. (1993), Prelusky et al. (1994b), Trenholm et al. (1994), and Rotter et al. (1995). 
suppression in feed intake. Under these conditions it is possible that defects in immunocompetence (Table 1) may contribute to the growth depression, perhaps resulting from the incidence of overt or sub-clinical disease. It should be noted that most of the recent studies on the effects of DON on feed intake in pigs (Table 1; Fig. 1) have been conducted with Fusarium-contaminated grain and the effects tend to be greater with such diets than with those supplemented with the pure form of the mycotoxin. In at least two instances (Bergsjo et al., 1992, 1993) limited quantities of other trichothecenes such as 3ADON and NIV were also present together with ZEN. It is may be significant that other trichothecenes including NIV and T-2 toxin have been implicated in both feed refusal and anorexia in pigs (Table 1). Thus, Rafai et al. (1995a) observed dose-related depressions in feed intake within one week of feeding diets contaminated with T-2 toxin. By the end of the 3 -week study pigs fed T-2 toxin at $3 \mathrm{mg} / \mathrm{kg}$ had feed intakes which were only 0.59 of control values. Furthermore, fusaric acid can enhance brain metabolism in pigs and a potential interaction with co-occurring DON has been proposed in feed refusal and emesis (D’Mello et al., 1997). Thus, additive or even synergistic effects on feed intake cannot be ruled out in studies based on the feeding of Fusarium-contaminated grain to pigs. It now also appears that NIV and DAS reduce feed intake in broiler chickens (Table 2) whereas DON has no effect on feed intake or growth (Kubena et al., 1997a). In mink, feed choice is affected by levels of DON as low as $0.28 \mathrm{mg} / \mathrm{kg}$ diet (Gibson et al., 1993). Dairy cows are considerably more tolerant to DON, as exemplified by the lack of effect on feed intake and milk production (Charmley et al., 1993; Ingalls, 1996). However, in Brazil poisoning of cattle fed citrus pulp has been attributed to contamination with DAS which has the potential to cause characteristic clinical symptoms including anorexia, weight loss, haemorrhagic lesions in vital organs and even death (Galhardo et al., 1997).

\subsubsection{Oral and other gastro-intestinal lesions}

Nivalenol, T-2 toxin and DAS induce gizzard erosions and oral lesions in poultry (Table 2). In the case of DAS, lesions are directly related to duration of exposure to the mycotoxin and to its concentration in the diet (D'Mello and Macdonald, 1998). Feeding a high fat diet to broiler chicks increases the growth depression caused by DAS, suggesting that such a diet facilitates lipid micellar absorption of the mycotoxin which is then able to inhibit protein synthesis at the ribosomal level. T-2 toxin also induces lesions in pigs, specifically on the mucosa of the pars oesophageal region, the incidence being doserelated. In addition, T-2 toxin can cause dermatitis of the snout, nose and buccal commissures in the pig (Table 1).

\subsubsection{Ill-thrift}

Although this condition is not universally recognised or adequately characterised, there is evidence for a distinct if ill-defined syndrome. Ovine ill-thrift occurs despite the presence of abundant and nutritious feeds and has been ascribed to a mixture of toxins present in pasture, some arising from fungal sources. However, as part of a study on ovine ill-thrift in Nova Scotia, Brewer et al. (1996) demonstrated a 44\% decline in feed intake of female lambs in the 4 days following a single intraruminal administration of 3-ADON. This was accompanied by a 5\% depression in apparent digestibility of the feed. Despite the clarity of these responses, the exact aetiology of ill-thrift remains nebulous, 
particularly in view of the occurrence of $F$. solani in soils of Nova Scotia. F. solani produces neosolaniol, DAS and T-2 toxin as the principal trichothecenes and judging by the effects observed in other animals (Tables 1 and 2) it is possible that ill-thrift in sheep may be the result of combinations of mycotoxins exerting additive or synergistic effects on feed intake.

\subsection{Zearalenone}

It is acknowledged that $\mathrm{ZEN}$ is of relatively low toxicity, with an $\mathrm{LD}_{50}$ value of $2-10 \mathrm{~g} /$ $\mathrm{kg}$ body weight as determined with mice (Flannigan, 1991). However, its role as a mammalian endocrine disrupter is being recognized, with effects in both males and females of different species, although evidence of its genotoxicity has recently emerged from studies with mice (Pfohl-Leszkowicz et al., 1995).

\subsubsection{Reproductive dysfunction}

Chronic investigations (Table 3) demonstrate that the estrogenic properties of ZEN towards mammals are an important feature at levels as low as $1.5-3 \mathrm{mg} / \mathrm{kg}$ diet. Thus, ZEN induces vulvovaginitis in premature gilts, anestrus in cycling females or delayed return into estrus post-weaning. During pregnancy, ZEN reduces embryonic survival when administered above a threshold level and sometimes decreases fetal weight. ZEN may affect the uterus by decreasing $\mathrm{LH}$ and progesterone secretion and by altering the morphology of uterine tissues (Etienne and Dourmad, 1994). In male pigs, ZEN can depress serum testosterone, weights of testes and spermatogenesis, while inducing feminisation and suppressing libido. In cows, infertility, reduced milk production and hyperestrogenism have been associated with ZEN or with Fusarium species producing this mycotoxin. When dairy heifers were fed ZEN over three estrous cycles, conception rates declined from 87 to $62 \%$ (Weaver et al., 1986). Additionally, ZEN from pastures in New Zealand has been implicated in the development of infertility in cattle and sheep (Towers and Sprosen, 1993). Possible additive or synergistic effects on fertility with T-2 toxin are possible since both often co-occur in Fusarium-contaminated feeds. Indeed, Hungarian studies suggest that under certain dietary conditions, ZEN and/or T-2 toxin may cause ovarian dysfunction in cows (Trucksess, 1997).

Fusarium fungi are capable of producing trans and cis forms of ZEN, $\alpha$-zearalenol and $\beta$-zearalenol on grain and all may contribute to estrogenic effects in mammals to varying extents. It is established that trans- $\alpha$-zearalenol is 3 to 4 times more estrogenic than ZEN (Richardson et al., 1985). The contribution of the different isomers in natural occurrences of reproductive disorders of cattle and sheep, as in New Zealand, needs to be assessed.

\subsection{Fumonisins}

The adverse effects of fumonisins has emerged as a predominant issue in mycotoxicology and is likely to remain so for some time. There is overwhelming evidence of diverse morphological, cellular and biochemical damage in farm animals fed fumonisin-contaminated diets. Profound effects in terms of lesions in the liver, gastrointestinal tract, brain and lungs have been reported in pigs poultry, calves and 
Table 3

Reproductive and other disorders induced by zearalenone

\begin{tabular}{|c|c|c|c|}
\hline Animal type & Conditions & Effects & Data source \\
\hline Sows & $\begin{array}{l}\text { Natural contamination or } \\
\text { addition of pure ZEN }\end{array}$ & $\begin{array}{l}\text { Vulvovaginitis, anestrus; delayed return to estrus post-weaning; reduced } \\
\text { embryonic survival; decreased luteinising hormone and progesterone secretion }\end{array}$ & $\begin{array}{l}\text { Review by Etienne and } \\
\text { Dourmad (1994) }\end{array}$ \\
\hline $\begin{array}{l}\text { Sows, gilts } \\
\text { and piglets }\end{array}$ & Fusarium-contaminated feed & $\begin{array}{l}\text { Reduced conception rates, litter size; stillbirths; enlargement of ovaries and } \\
\text { uterus; swelling of vulva in piglets }\end{array}$ & Vanyi et al. (1994c) \\
\hline Piglets & $\begin{array}{l}\text { Piglets suckling sows fed } \\
\text { contaminated grain }\end{array}$ & $\begin{array}{l}\text { Edematous swelling and reddening of vulva; necrosis of tail; congenital lesions } \\
\text { of the external genitalia }\end{array}$ & Dacasto et al. (1995) \\
\hline Boars & $\begin{array}{l}\text { Natural contamination or } \\
\text { addition of pure ZEN }\end{array}$ & $\begin{array}{l}\text { Depression of serum testosterone, testes weight and spermatogenesis; } \\
\text { feminisation and suppression of libido }\end{array}$ & $\begin{array}{l}\text { Review by Diekman and } \\
\text { Green (1992) }\end{array}$ \\
\hline Cows & Pure ZEN & Infertility; reduced milk production; hyperestrogensim; depressed conception rates & Weaver et al. (1986) \\
\hline $\begin{array}{l}\text { Cattle and } \\
\text { sheep }\end{array}$ & Pastures in New Zealand & Infertility; increased number of barren ewes and fewer ewes with twins & Towers and Sprosen (1993) \\
\hline Mink & Pure ZEN & $\begin{array}{l}\text { Severe endometrial hyperplasia of uterus; uterine atrophy; endometritis; } \\
\text { degeneration and atrophy of ovarian follicles; reduced reproductive performance }\end{array}$ & Yamini et al. (1997) \\
\hline Rabbits & Pure ZEN & $\begin{array}{l}\text { Reduced bodyweight; histopathological changes in liver, kidneys and } \\
\text { uterus; females highly susceptible }\end{array}$ & Abdelhamid et al. (1992) \\
\hline Rats & Pure ZEN & Reduced serum testosterone levels and sperm counts & Kaliamurthy et al. (1997) \\
\hline Mice & Pure ZEN & Persistent estrous; sterility & Ito and Ohtsubo (1994) \\
\hline Mice & Pure ZEN & Genotoxic; induction of hepatocellular adenomas & Pfohl-Leszkowicz et al. (1995) \\
\hline
\end{tabular}


Table 4

Adverse effects of fumonisins in farm livestock

\begin{tabular}{|c|c|c|}
\hline Animal species/type & Effects & Data source \\
\hline Weanling pigs & $\begin{array}{l}\text { Nodular hyperplasia of liver; oesophageal lesions; } \\
\text { gastric ulceration }\end{array}$ & Casteel et al. (1993) \\
\hline Weaned piglets & Dose-dependent induction of pulmonary edema & Zomborszky et al. (1997a) \\
\hline Weaned piglets & Pulmonary edema; death & Fazekas et al. (1998) \\
\hline Growing pigs & $\begin{array}{l}\text { Reduced weight gain; erratic growth and feed intake } \\
\text { patterns; increased serum cholesterol; increased ratios } \\
\text { of sphinganine to sphingosine in liver, lung and kidney }\end{array}$ & Rotter et al. (1996) \\
\hline Growing pigs & Increased liver and lung weights & Harvey et al. (1996) \\
\hline Growing-finishing pigs & $\begin{array}{l}\text { Increased variability in feed intake and carcass fat } \\
\text { content; elevated serum cholesterol }\end{array}$ & Rotter et al. (1997) \\
\hline Growing pigs & Reduced pulmonary clearance; predisposition to disease & Smith et al. (1996a) \\
\hline Growing pigs & Pulmonary hypertension & Smith et al. (1996b) \\
\hline Chicken embryos & $\begin{array}{l}\text { Dose- and time-related mortality (up to } 100 \% \text { ); } \\
\text { hydrocephalus, enlarged beaks and elongated necks in } \\
\text { embryos; pathological lesions in internal organs }\end{array}$ & Javed et al. (1993a) \\
\hline Chicken embryos & $\begin{array}{l}\text { Sub-cutaneous and hepatic haemorrhages; disruption } \\
\text { of sphingoid metabolism }\end{array}$ & Zacharias et al. (1996) \\
\hline Broiler chickens & $\begin{array}{l}\text { Dose-related clinical manifestations; reductions in } \\
\text { weight gain and increase in mortality }\end{array}$ & Javed et al. (1993b) \\
\hline Laying hens & Diarrhoea & Prathapkumar et al. (1997) \\
\hline Calves & $\begin{array}{l}\text { Increases in serum enzyme levels; mild microscopic } \\
\text { hepatic lesions; impaired lymphocyte blastogenesis }\end{array}$ & Osweiler et al. (1993) \\
\hline Horses & $\begin{array}{l}\text { Equine leukoencephalomalacia: liquefactive necrosis } \\
\text { of cerebral white matter; severity of lesions related } \\
\text { to duration of exposure }\end{array}$ & Schumacher et al. (1995) \\
\hline Horses & $\begin{array}{l}\text { Equine leukoencephalomalacia: reduced appetite, } \\
\text { ataxia, edema of lungs and brain, death }\end{array}$ & $\begin{array}{l}\text { Fazekas and Bajmocy } \\
(1996)\end{array}$ \\
\hline
\end{tabular}

equine animals (Table 4). There is also evidence of an immunosuppressive dimension in its toxicity to farm animals. For example, Smith et al. (1996a) concluded that, even at sub-lethal doses for the pig, fumonisins can inhibit the action of pulmonary intravascular macrophages in the removal of particulate matter and pathogens from the circulation. Animals may therefore become more susceptible to disease. Dose- and time-related mortality is another feature of fumonisin toxicology (Javed et al., 1993a, b; Fazekas and Bojmocy, 1996). In addition, it is becoming increasingly apparent that a part of the action of the fumonisins hinges on structural analogy. $\mathrm{FB}_{1}$ bears a remarkable resemblance to sphinganine and sphingosine, intermediates in the biosynthesis and degradation of sphingolipids (D'Mello et al., 1997). Indeed, it has been demonstrated in vitro and in situ that $\mathrm{FB}_{1}$ blocks sphingolipid biosynthesis by specifically inhibiting sphingosine (sphinganine) $\mathrm{N}$-acyltransferase. A consequence of this inhibition is the accumulation of sphingoid bases in the sera of ponies, pigs and rats fed contaminated corn or culture material from $F$. moniliforme containing known levels of $\mathrm{FB}_{1}$. Indeed, tissue and serum sphinganine ( $\mathrm{Sa}$ ) to sphingosine (So) ratios can be used as markers to indicate exposure of animals to fumonisins. Over recent years a number of fumonisin-linked syndromes have been established or proposed. 


\subsubsection{Equine leukoencephalomalacia (ELEM)}

Feeding corn contaminated with $F$. moniliforme or culture material derived from this fungus may result in the induction of equine leukoencephalomalacia (ELEM). Cases of ELEM have been confirmed in Hungary, Brazil, South Africa and the USA (Marasas, 1995) and have been attributed specifically to the activity of fumonisins. ELEM is an acutely fatal neurological disorder of horses and donkeys with clinical signs such as ataxia, paresis, hypersensitivity and locomotor derangements. Lesions in the brain comprise liquefactive necrosis in one or both hemispheres. Oedema of both brain and lungs may also occur (Table 4). Serum Sa: So ratios are also markedly increased by feeding culture material of F. moniliforme to horses (Goel et al., 1996).

\subsubsection{Duodenitis/proximal jejunitis (DPJ)}

Duodenitis/proximal jejunitis (DPJ) is a condition characterised by copious, often haemorrhagic gastric reflux, affecting horses over two years of age (Schumacher et al., 1995). Lesions include mucosal and sub-mucosal edema in mild cases and sloughing of villus epithelium, villus atrophy and haemorrhage in severe cases. The cause of DPJ remains to be elucidated. Although Schumacher et al. (1995) were unsuccessful in reproducing the clinical signs of DPJ in horses fed $F$. moniliforme culture material, they were unable to definitively exclude toxins from this fungus in the aetiology of the syndrome.

\subsubsection{Porcine pulmonary edema (PPE)}

The porcine manifestation of fumonisin toxicity is characterised by pulmonary edema (PPE) (Table 4) as well as pancreatic and liver damage, with cases confirmed in Hungary, Brazil and the USA. A dose-dependent relationship has been observed (Zomborszky et al., 1997a). Elevated serum cholesterol levels appears to be consistent feature of the condition and hepatic enzymes may also be enhanced. Pulmonary hypertension caused by hypoxic vasoconstriction has also been implicated in PPE. Pigs fed fumonisins showed enhanced pulmonary artery pressure, decreased heart rate, cardiac output and mixed venous $\mathrm{O}_{2}$ tension (Smith et al., 1996b).

In studies on the chronic toxicity of $\mathrm{FB}_{1}$, weanling pigs fed a diet containing the mycotoxin at $100 \mathrm{mg} / \mathrm{kg}$ for 7 days followed by a diet containing $190 \mathrm{mg} / \mathrm{kg}$ for 83 days, developed nodular hyperplasia of the liver (Casteel et al., 1993). These nodules, of various diameters, were composed of solid sheets or nests of hepatocytes. In other pigs, the formation of papillary downgrowths of the stratum basale of the distal oesophageal mucosa were observed. Although incidence of PPE has not been reported in other studies (Rotter et al., 1996), increased Sa : So ratios have been observed with fumonisin levels of $10 \mathrm{mg} / \mathrm{kg}$ diet. At lower fumonisin levels, erratic feed intake and growth patterns and increased carcass fat content may also occur (Table 4).

\subsubsection{Acute mortality syndrome}

Field observations have implicated fumonisin-containing maize in an acute mortality syndrome of broiler chickens. The condition is characterised by markedly increased mortality in chicks between 10 and 16 days of age. Javed et al. (1993a,b) observed doserelated increases in mortality of chicken embryos and of broiler chicks following dietary 
administration of pure $\mathrm{FB}_{1}$. MON also enhanced mortality in broiler chicks but the onset was accelerated after feeding the two mycotoxins together. Since maize may be contaminated with both $\mathrm{FB}_{1}$ and $\mathrm{MON}$, it is possible that the syndrome represents the additive effect of the two mycotoxins. Ledoux et al. (1995) also observed enhanced mortality in broiler chicks following dietary administration of MON but questioned whether it was by itself involved in the syndrome as it occurs under commercial conditions. In contrast, Vesonder and Wu (1998) implicated MON and not $\mathrm{FB}_{1}$ in acute death of ducklings. The evidence was derived from feeding studies involving Fusarium culture materials and pure mycotoxins. An assessment of the effects of MON on mortality in poultry may be compounded by species differences. Vesonder and Wu (1998) noted that ducklings were more sensitive to the lethal effects of MON than turkey poults which in turn were more sensitive than chicks.

\subsection{Moniliformin}

In addition to inducing mortality and to its putative interaction with fumonisins, MON is endowed with cardiotoxic effects in a wide range of laboratory and domesticated animals including rats, chickens, turkeys and ducks. Primary lesions include myocardial degeneration and necrosis in all these species. Ledoux et al. (1995) reported that just $50 \mathrm{mg} / \mathrm{kg}$ diet enhanced heart weights in broiler chickens. Gross lesions included generalised cardiomegaly with dilation of the right ventricle. Histopathological changes included a high incidence of variable-sized cardiomyocyte nuclei, with numerous large round and oval nuclei.

\subsection{Embryotoxicity and teratogenic effects}

The chick embryo is regularly used in mycotoxicology as a rapid and cost-effective assay model and the prospects are that interest will continue as more emphasis is placed on the elucidation of interactions among co-occurring mycotoxins. However, its limitations must be recognised. For example, the chick embryo cannot excrete xenobiotics such as mycotoxins and metabolic transformations are largely restricted. Nevertheless, recent results are consistent with those observed in conventional experiments. Thus, Javed et al. (1993a) observed embryo mortality on inoculating fertile chicken eggs with $\mathrm{FB}_{1}$, effects which were dependent upon duration of exposure and dose level and which were replicated in trials with broiler chicks. In addition, however, evidence of embryonic deformities was presented (Table 4). Zacharias et al. (1996) observed dysfunction of sphingoid metabolism in chick embryos exposed to $\mathrm{FB}_{1}$, as in pigs and horses, and furthermore correlated these changes with gross morphological aberrations.

Placental transfer of ZEN can result in teratogenic effects in piglets following consumption of contaminated feed by sows. Dacasto et al. (1995) reported findings of an outbreak in Italy where sows showed no overt signs of hyperoestrogenism, but both male and female piglets from these dams were affected by various abnormalities of the genitalia (Table 3).

Teratogenic effects have also been observed in sows fed fumonisin-containing diets based on a culture of $F$. moniliforme (Zomborszky et al., 1997b). Preliminary results 
indicated that feeding such diets to sows in advanced stages of pregnancy caused fetal damage to the extent that PPE of particular severity was evident in piglets slaughtered immediately after parturition. It is implied that fumonisins contained in the culture elicit adverse effects through placental transfer. In rats, teratogenicity of $\mathrm{FB}_{1}$ is expressed as a suppression of growth and bone development in the fetus (Lebepe-Mazur et al., 1995).

\subsection{Cytotoxicity}

Assays based on isolated cells have emerged as useful adjuncts to whole-animal toxicology, yielding supplementary information on physiological and biochemical modes of action. $\mathrm{FB}_{1}$, for example, causes morphological and functional abnormalities in chicken macrophages in vitro, indicative of an immunosuppressive effect . Chicken macrophage viability may be reduced by exposure to T-2 tetraol, a derivative of T-2 toxin (Kidd et al., 1997). Other studies suggest that the cytotoxicity of MON in an L6 myoblast in vitro model arises partly from oxidative damage and altered pyruvate metabolism (Reams et al., 1996). In pig kidney cells, elevated sphingoid bases and complex sphingolipid depletion were identified as the basis of the cytotoxic action of $\mathrm{FB}_{1}$ (Yoo et al., 1996). The metabolic changes are not dissimilar to those seen in whole-animal studies (Table 4).

A particular attribute of cytotoxicity models is their potential application in screening procedures with grain or animal feed suspected to be contaminated with mycotoxins. A rapid colorimetric bioassay for screening of Fusarium mycotoxins has been developed (Rotter et al., 1993). Such procedures may also initiate a search for as yet unidentified mycotoxins in grain and feed. D'Mello et al. (1993), for example, showed that grain extracts obtained from a particular harvest of barley were lethal to two mammalian cell lines, although the identity of the toxic substances has remained elusive.

\subsection{Interactions}

Under commercial conditions, livestock are exposed to a complex mixture of mycotoxins derived not only from Fusarium fungi but from the Aspergilli as well. If the net effect is additive then it might be possible to predict the outcome in terms of productivity. Recent evidence, (Table 5) indicates that most interactions involving Fusarium mycotoxins are less than additive or additive for responses ranging from mortality (Javed et al., 1993a) to feed intake and growth (Harvey et al., 1996; Kubena et al., 1997a). However, three reports summarised in Table 5 indicate synergistic effects of DON and fusaric acid; DON and $\mathrm{FB}_{1}$; and DAS and aflatoxins. In addition, potentiation may occur between co-occurring mycotoxins. Although of minor toxicity at levels detected in nature, fusaric acid can enhance the activity of other Fusarium mycotoxins. Thus, a toxic interaction between fusaric acid and $\mathrm{FB}_{1}$ has been demonstrated in the fertile chicken egg. In combination, high lethality was observed whereas individually the mycotoxins had virtually no effect on mortality (D'Mello et al., 1997). Similarly, Kubena et al. (1997a) observed that serum protein and urea nitrogen in broilers were increased only by the $\mathrm{FB}_{1}$ and DON combination, while serum Ca levels were increased only by the 
Table 5

Interactions involving Fusarium mycotoxins

\begin{tabular}{|c|c|c|c|c|c|}
\hline Source of mycotoxins & Combinations & Animal species & Responses & Interaction & Data source \\
\hline Naturally contaminated grains & DON and fusaric acid & Pigs & Growth & Synergistic & Smith et al. (1997) \\
\hline $\begin{array}{l}\text { Inoculated maize and pure } \\
\text { mycotoxin }\end{array}$ & DON and $\mathrm{T}-2$ toxin & Pigs & Feed intake and growth & $\begin{array}{l}\text { Adverse effects of DON } \\
\text { reduced at intermediate } \\
\text { levels of T- } 2 \text { toxin }\end{array}$ & Friend et al. (1992) \\
\hline $\begin{array}{l}\text { Contaminated wheat and } \\
\text { culture material }\end{array}$ & $\mathrm{DON}$ and $\mathrm{FB}_{1}$ & Pigs & Weight gain & Synergistic & Harvey et al. (1996) \\
\hline Pure mycotoxins & $\mathrm{T}-2$ toxin and $\mathrm{OA}$ & Pigs & $\begin{array}{l}\text { Feed intake and } \\
\text { weight gain }\end{array}$ & Additive & Harvey et al. (1994) \\
\hline $\begin{array}{l}\text { Culture material and pure } \\
\text { mycotoxin }\end{array}$ & DON and MON & Broiler chicks & $\begin{array}{l}\text { Feed intake and } \\
\text { weight gain }\end{array}$ & Less than additive & Harvey et al. (1997) \\
\hline $\begin{array}{l}\text { Culture material and } \\
\text { contaminated wheat }\end{array}$ & DON and fumonisins & Broiler chicks & Weight gain & Less than additive & Kubena et al. (1997a) \\
\hline $\begin{array}{l}\text { Pure mycotoxin and culture } \\
\text { material }\end{array}$ & $\begin{array}{l}\mathrm{T}-2 \text { toxin and } \\
\text { fumonisins }\end{array}$ & Broiler chicks & Weight gain & Additive & Kubena et al. (1997a) \\
\hline Pure mycotoxins & $\mathrm{FB}_{1}$ and moniliformin & Broiler chicks & Mortality & Additive & Javed et al. (1993a) \\
\hline \multirow[t]{2}{*}{$\begin{array}{l}\text { Pure mycotoxin and culture } \\
\text { material }\end{array}$} & $\begin{array}{l}\mathrm{T}-2 \text { toxin and } \\
\text { fumonisins }\end{array}$ & Turkey poults & Weight gain & Additive & Kubena et al. (1995) \\
\hline & & & $\begin{array}{l}\text { Certain blood and } \\
\text { enzyme values }\end{array}$ & Synergistic & \\
\hline $\begin{array}{l}\text { Culture material and pure } \\
\text { mycotoxins }\end{array}$ & DAS, fumonisins or OA & Turkey poults & Weight gain & $\begin{array}{l}\text { Additive or less } \\
\text { than additive }\end{array}$ & Kubena et al. (1997b) \\
\hline $\begin{array}{l}\text { Inoculated rice and pure } \\
\text { mycotoxin }\end{array}$ & DAS and aflatoxins & Lambs & $\begin{array}{l}\text { Weight gain and serum } \\
\gamma \text {-glutamyl transferase }\end{array}$ & Synergistic & Harvey et al. (1995) \\
\hline
\end{tabular}


$\mathrm{FB}_{1}$ and $\mathrm{T}-2$ toxin combination. In turkeys, haematological criteria such as haemoglobin and haematocrit values were increased only by the T-2 toxin and $\mathrm{FB}_{1}$ combination whereas individually the mycotoxins were without effect (Kubena et al., 1995). It has been concluded that although fumonisin levels in poultry feeds are not intrinsically problematic, the risk is heightened by the synergistic and potentiating interactions with other co-occurring mycotoxins.

\section{Residues}

Residues may arise through carry-over into eggs, milk, meat and offal and, as such, may represent a potential risk to humans. Prelusky et al. (1987) found relatively low but measureable levels of radio-labelled DON in eggs from hens fed a diet contaminated with the mycotoxin. However, residues declined once the contaminated feed was removed. Of some concern, nevertheless, was the observation that only 0.10 of the radioactivity in egg components could be attributed to DON itself, while the nature of its major metabolites remained obscure. Feeding pigs on ZEN-contaminated diets may also result in detectable amounts of residues. Thus, kidney and liver contained, respectively, up to 4.3 and $4.9 \mathrm{ng} \mathrm{ZEN/g} \mathrm{(Lusky} \mathrm{et} \mathrm{al.,} \mathrm{1997).} \mathrm{In} \mathrm{contrast,} \mathrm{lactational} \mathrm{transfer} \mathrm{of}$ fumonisins into milk of dairy cows is considered by Richard et al. (1996) to be minimal, at a daily dosage level of $3 \mathrm{mg} \mathrm{FB}_{1} / \mathrm{kg}$ bodyweight for 14 days. Similarly, in lactating sows ingesting non-lethal doses of $\mathrm{FB}_{1}$, the mycotoxin was absent in the milk, and piglets suckling these sows showed no overt or biochemical evidence of toxicity (Becker et al., 1995).

\section{Advisory and tolerance limits}

Despite the established carcinogenicity of the fumonisins, statutory regulations do not exist for these or any of the other Fusarium mycotoxins. In contrast, stringent directives are in place for the Aspergillus-derived aflatoxins. However, a selection of advisory and tolerance limits for the Fusarium mycotoxins are available in the literature (Table 6). The data are not designed to be exhaustive, but rather illustrative of global values published in the last three to four years. Compilation of data for a particular mycotoxin is fraught with difficulties arising from expected variation between studies and from the criteria used to develop estimates of tolerance. Dose of in terms of intake is more important in determining toxicity than dietary levels. In addition, rates of detoxification of absorbed mycotoxins will have an impact on the eventual outcome. It should also be recognized that no allowance has been made for additive or synergistic effects arising from co-occurring mycotoxins. Consequently, discrepancies will inevitably arise between estimates based on the feeding of Fusarium-contaminated grain and those derived from studies with a single pure mycotoxin (Prelusky et al., 1994b). The use of the pure form, however, may still result in differences in estimates. Thus, Rafai et al. (1995a) commented that feed refusal in pigs fed T-2 toxin at $3 \mathrm{mg} / \mathrm{kg}$ was a particular problem whereas other earlier studies had indicated no such effects at 
Table 6

Estimates of advisory or tolerance limits for Fusarium mycotoxins

\begin{tabular}{|c|c|c|c|}
\hline Mycotoxins & Class of animals & Levels & Data source \\
\hline DON & Cattle and chickens & $\begin{array}{l}10 \mathrm{mg} / \mathrm{kg} \text { grain and } \\
\text { grain by-products }\end{array}$ & FDA; in Trucksess et al. (1995) \\
\hline DON & Pigs & $\begin{array}{l}5 \mathrm{mg} / \mathrm{kg} \text { grain and } \\
\text { grain by-products }\end{array}$ & FDA; in Trucksess et al. (1995) \\
\hline DON & Growing pigs & $0.5-1.0 \mathrm{mg} / \mathrm{kg}$ diet & Bergsjo et al. (1992) \\
\hline DON plus ZEN & $\begin{array}{l}\text { Growing chicks; } \\
\text { laying hens }\end{array}$ & $\begin{array}{l}\text { DON: } 3 \mathrm{mg} / \mathrm{kg}+ \\
\text { ZEN: } 0.6 \mathrm{mg} / \mathrm{kg} \text { diet }\end{array}$ & Keshavarz (1993) \\
\hline DON & Ducks & $6 \mathrm{mg} / \mathrm{kg}$ wheat & Boston et al. (1996) \\
\hline DON & Dairy cows & $\begin{array}{l}15 \mathrm{mg} / \mathrm{kg} \text { barley or } \\
31 \mathrm{mg} / \mathrm{kg} \text { bodyweight }\end{array}$ & Ingalls (1996) \\
\hline $\mathrm{T}-2$ toxin & Growing pigs & $<0.5 \mathrm{mg} / \mathrm{kg}$ diet & Rafai et al. (1995a) \\
\hline ZEN & Pigs & $500 \mathrm{mg} / \mathrm{kg}$ feed & Diaz and Cespedes (1997) \\
\hline ZEN plus NIV & Pregnant sows & $\begin{array}{l}\mathrm{ZEN}: 1.8 \mathrm{mg} / \mathrm{kg}+ \\
\mathrm{NIV}: 6.9 \mathrm{mg} / \mathrm{kg} \text { diet }\end{array}$ & Williams and Blaney (1994) \\
\hline ZEN & Sheep & $<3 \mathrm{mg} / \mathrm{kg}$ forage & Kramer et al. (1997) \\
\hline $\mathrm{FB}_{1}$ & Weaned piglets & $<10 \mathrm{mg} / \mathrm{kg}$ feed & Zomborszky et al. (1997a) \\
\hline $\mathrm{FB}_{1}$ & Weanling gilts & $70 \mathrm{mg} / \mathrm{kg}$ feed & Guzman et al. (1997) \\
\hline $\mathrm{FB}_{1}$ & Growing pigs & $<0.1 \mathrm{mg} / \mathrm{kg}$ feed & Rotter et al. (1996) \\
\hline MON & Broiler chickens & $<50 \mathrm{mg} / \mathrm{kg}$ feed & Ledoux et al. (1995) \\
\hline
\end{tabular}

considerably higher levels of the mycotoxin. The choice of performance and biochemical criteria may also influence selection of tolerance values. For example, Rotter et al. (1996) suggested that for $\mathrm{FB}_{1}$ erratic growth occurred in growing pigs at levels as low as $0.1 \mathrm{mg} / \mathrm{kg}$ diet, followed by reduced growth and biochemical abnormalities in blood at $1 \mathrm{mg} / \mathrm{kg}$ diet. If sphingolipid aberration in tissues are used as the criterion, then changes would not occur until diets contained $10 \mathrm{mg} \mathrm{FB}_{1} / \mathrm{kg}$. It is difficult to reconcile the value of $70 \mathrm{mg} / \mathrm{kg}$ feed (Table 6) for gilts in the study of Guzman et al. (1997) even with suggestions that males are more sensitive than females to the effects of $\mathrm{FB}_{1}$ (Rotter et al., 1996). The importance of choice of criteria is clearly evident in the case of MON. According to Ledoux et al. (1995), significant increases in mortality of broiler chicks are not observed until dietary levels of MON exceed $200 \mathrm{mg} / \mathrm{kg}$. If feed intake depression is to be avoided, then levels must not exceed $100 \mathrm{mg} / \mathrm{kg}$, and if normal heart weight is the selected criterion, levels of MON should remain below $50 \mathrm{mg} / \mathrm{kg}$ diet (Table 6).

\section{De-contamination and amelioration}

A number of de-contamination procedures have been investigated, broadly divisible into physical and chemical principles (Placinta et al., 1999). Physical methods include milling which has been shown to be highly effective for DON, and density segregation which has resulted in reduced levels of trichothecenes and ZEN. Superactivated charcoal is partially effective at reducing the incidence of oral lesions in broilers fed T-2 toxin, but 
mortality remains unaffected (Edrington et al., 1997). Furthermore, amelioration of oral lesions was not consistent between experiments. Chemical methods tested include calcium hydroxide monomethylamine, sodium bisulphite and ammonia. The commercial potential of these de-contamination procedures, however, has yet to be determined.

Anti-oxidants such as vitamin $\mathrm{E}$ have been considered as dietary supplements to counteract the effect of T-2 toxin. A partial beneficial effect, in terms of reduced in vivo lipid peroxidation, has been reported in one study with chickens (Hoehler and Marquardt, 1996). Vitamin C was ineffective in this respect.

The general consensus now prevailing is that preventive measures offer greater potential than remedial procedures. With ZEN, a feeding strategy for breeding ewes has been suggested, based on the use of chicory pastures containing inherently low levels of the mycotoxin (Kramer et al., 1997). However, selection of cultivars of cereal and forage plants that are resistant to infection by toxigenic species of Fusarium pathogens is likely to be the long-term objective of any effort to control contamination with the associated mycotoxins.

\section{Conclusions}

The major Fusarium mycotoxins occurring in animal feeds and forages include the trichothecenes, zearalenone and its derivatives, and fumonisins. A number of compounds within these three groups have been implicated in spontaneous worldwide cases of mycotoxicoses in livestock. In addition, chronic exposure occurs by virtue of continuing global contamination of cereal grains and forages. Of the trichothecenes, DON and T-2 toxin and DAS are associated with particular syndromes. DON is conventionally linked with emesis, feed refusal and reduced feed intake in pigs, but T-2 toxin and NIV may also exert effects in this respect. In poultry, T-2 toxin and DAS are clearly associated with oral lesions. There is unequivocal evidence implicating ZEN in reproductive disorders of pigs, cattle and sheep, but limited evidence suggests that T-2 toxin may produce similar effects. Fumonisins are definitively linked with porcine pulmonary edema and equine leukoencephalomalacia and with disruption of sphingolipid metabolism in affected animals. In addition, Fusarium mycotoxins are tentatively implicated in ill-thrift of sheep, acute mortality syndrome of poultry and, to a lesser extent, in duodenitis/proximal jejunitis of horses. Furthermore, underlying features of immunotoxicity and teratogenicity must be considered in assessing risk from these mycotoxins. Additive interactions in precipitation of adverse effects in pigs and/or poultry have been identified between T-2 toxin and ochratoxin; DON and MON; DON and fumonisins; T-2 toxin and fumonisins; $\mathrm{FB}_{1}$ and $\mathrm{MON}$; DAS and fumonisins. Of greater concern are synergistic interactions between $\mathrm{DON}$ and fusaric acid; and $\mathrm{DON}$ and $\mathrm{FB}_{1}$ observed with pigs and between DAS and aflatoxins in lambs. Equally, potentiation between $\mathrm{FB}_{1}$ and $\mathrm{DON}$ or T-2 toxin for several serum components in poultry is worthy of note. Such interactions also impose difficulties in the provision of reliable values for tolerance and regulatory limits. Finally, it is suggested that the long-term objective should be to reduce natural contamination of cereal grains and forages through the exploitation of disease-resistant cultivars. 


\section{Acknowledgements}

This work was supported by funding from the Scottish Office Agriculture, Environment and Fisheries Department, the University of Edinburgh and the Overseas Research Student scheme.

\section{References}

Abdelhamid, A.M., Kelada, I.P., Ali, M.M., El-Ayouty, S.A., 1992. Influence of zearalenone on some metabolic, physiological and pathological aspects of female rabbits at two different ages. Arch. Anim. Nutr. 42, 63-70.

Ademoyero, A.A., Hamilton, P.B., 1991. Mouth lesions in broiler chickens caused by scirpenol mycotoxins. Poult. Sci. 70, 2082-2089.

Becker, B.A., Pace, L., Rottinghaus, G.E., Shelby, R., Misfeldt, M., Ross, P.F., 1995. Effects of feeding fumonisin $B_{1}$ in lactating sows and their suckling pigs. Am. J. Vet. Res. 56, 1253-1258.

Bergsjo, B., Matre, T., Nafstad, I., 1992. Effects of diets with graded levels of deoxynivalenol on performance in growing pigs. J. Vet. Med. Series A 39, 752-758.

Bergsjo, B., Langseth, W., Nafstad, I., Hogset Jansen, J., Larsen, H.J.S., 1993. The effects of naturally deoxynivalenol-contaminated oats on the clinical condition, blood parameters, performance and carcass composition of growing pigs. Vet. Res. Comm. 17, 283-294.

Biehl, M.L., Prelusky, D.B., Koritz, G.D., 1993. Biliary excretion and enterohepatic cycling of zearalenone in immature pigs. Toxicol. Appl. Pharmacol. 121, 152-159.

Boston, S., Wobeser, G., Gillespie, M., 1996. Consumption of deoxynivalenol-contaminated wheat by mallard ducks under experimental conditions. J. Wildlife Dis. 32, 17-22.

Brewer, D., Mcalees, A.J., Taylor, A., 1996. Ovine ill-thrift in Nova Scotia. 13. Anorexia and digestibility decline in female lambs given 3,7,11- ${ }^{3} \mathrm{H}_{3}$-3-acetoxy-7,15-dihydroxy-12,3-epoxytrichothec-9-en-8-one. Proc. Nova Scotia Inst. Sci. 41, 39-47.

Casteel, S.W., Turk, R.P., Cowart, R.P., Rottinghaus, G.E., 1993. Chronic toxicity of fumonisin in weanling pigs. J. Vet. Diagn. Invest. $5,413-417$.

Charmley, E., Trenholm, H.L., Thompson, B.K., Vudathala, D., Nicholson, J.W.G., Prelusky, D.B., Charmley, L.L., 1993. Influence of level of deoxynivalenol in the diet of dairy cows on feed intake, milk production , milk production and its composition. J. Dairy Sci. 76, 3580-3587.

Dacasto, M., Rolando, P., Nachtmann, C., Ceppa, L., Nebbia, C., 1995. Zearalenone mycotoxicosis in piglets suckling sows fed contaminated grain. Vet. Human Toxicol. 37, 359-361.

Diaz, G.J., Cespedes, A.E., 1997. Natural occurrence of zearalenone in feeds and feedstuffs used in poultry and pig nutrition in Colombia. Mycotoxin Res. 13, 81-87.

Diekman, M.A., Green, M.L., 1992. Mycotoxins and reproduction in domestic livestock. J. Anim. Sci. 70, 16151627.

D’Mello, J.P.C., Macdonald, A.M.C., 1997. Mycotoxins. Anim. Feed Sci. Technol. 69, 155-166.

D’Mello, J.P.F., Macdonald, A.M.C., 1998. Fungal toxins as disease elicitors. In: Rose, J. (Ed.), Environmental Toxicology: Current Developments. Gordon and Breach, London, pp. 253-289.

D’Mello, J.P.F., Macdonald, A.M.C., Cochrane, M.P., 1993. A preliminary study of the potential for mycotoxin production in barley grain. Aspects Appl. Biol. 36, 375-382.

D’Mello, J.P.F., Porter, J.K., Macdonald, A.M.C., Placinta, C.M., 1997. Fusarium mycotoxins. In: D’Mello J.P.F. (Ed.), Handbook of Plant and Fungal Toxicants. CRC Press, Boca Raton, pp. 287-301.

D’Mello, J.P.F., Macdonald, A.M.C., Postel, D., Dijksma, W.P.T., Dujardin, A., Placinta, C.M., 1998. Pesticide use and mycotoxin production in Fusarium and Aspergillus phytopathogens, Europ. J. Plant Pathol., 104, $741-751$.

Edrington, T.S., Kubena, L.F., Harvey, R.B., Rottinghaus, G.E., 1997. Influence of a superactivated charcoal on the toxic effects of aflatoxin or T-2 toxin in growing broilers. Poult. Sci. 76, 1205-1211.

Etienne, M., Dourmad, J.Y., 1994. Effects of zearalenone or glucosinolates in the diet on reproduction in sows: a review. Livest. Prod. Sci. 99-113. 
Fazekas, B., Bajmocy, E., 1996. Occurrence of equine leukoencephalomalacia caused by fumonisin-B1 mycotoxin in Hungary. Magy. Allatorv. Lap. 51, 484-487.

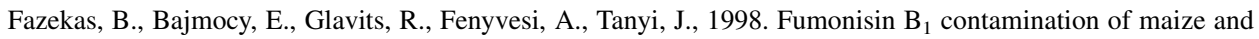
experimental acute fumonisin toxicosis in pigs. J. Vet. Med. Series B 45, 171-181.

Fekete, S., Huszenicza, G., Szilagyi, M., Albert, M., Szilagyi, A., 1992. Effect of long-term feeding of sublethal quantities of T-2 toxin upon the ovarian activity of the rabbit. J. Appl. Rabbit Res. 15, 583-593.

Flannigan, B., 1991. Mycotoxins. In: D’Mello, J.P.F. Duffus, C.M., Duffus, J.H. (Eds.), Toxic Substances in Crop Plants, The Royal Society of Chemistry, Cambridge, pp. 226-257.

Friend, D.W., Thompson, B.K., Trenholm, H.L., Boermans, H.J., Hartin, K.E., and Panich, P.L., 1992. Toxicity of T-2 toxin and its interaction with deoxynivalenol when fed to young pigs. Can. J. Anim. Sci. 72, 703-711.

Galhardo, M., Birgel, E.H., Soares, L.M.V., Furlani, R.P.Z., 1997. Poisoning by diacetoxyscirpenol in cattle fed citrus pulp in the state of Sao Paulo, Brazil. Braz. J. Vet. Res. Anim. Sci. 34, 90-91.

Gibson, M.K., Bursian, S.J., Aulerich, R.J., 1993. Effects of deoxynivalenol on feed consumption and body weight gains in mink (Mustela vison). Bull. Environ. Contam. Toxicol. 51, 6-11.

Goel, S., Schumacher, J., Lenz, S.D., Kemppainen, B.W., 1996. Effects of Fusarium moniliforme isolates on tissue and serum sphingolipid concentrations in horses. Vet. Human Toxicol. 38, 265-270.

Guzman, R.E., Casteel, S.W., Rottinghaus, G.E., Turk, J.R., 1997. Chronic consumption of fumonisins derived from Fusarium moniliforme culture material: clinical and pathologic effects in swine. J. Vet. Diag. Invest. 9, 216-218.

Harvey, R.B., Kubena, L.F., Elissalde, M.H., Rottinghaus, G.E., Corrier, D.E., 1994. Administration of ochratoxin A and T-2 toxin to growing swine. Am. J. Vet. Res. 55, 1757-1761.

Harvey, R.B., Edrington, T.S., Kubena, L.F., Elissalde, M., Corrier, D.E., Rottinghaus, G.E., 1995. Effect of aflatoxin and diacetoxyscirpenol in ewe lambs. Bull. Environ. Contam. Toxicol. 54, 325-330.

Harvey, R.B., Edrington, T.S., Kubena, L.F., Elissalde, M., Casper, H.H., Rottinghaus, G.E., Turk, J.R., 1996. Effects of dietary fumonisin $\mathrm{B}_{1}$-containing culture material, deoxynivalenol-contaminated wheat, or their combination on growing barrows. Am. J. Vet. Res. 57, 1790-1794.

Harvey, R.B., Kubena, L.F., Rottinghaus, G.E., Turk, J.R., Casper, H.H., Buckley, S.A., 1997. Moniliformin from Fusarium fujikuroi culture material and deoxynivalenol from naturally contaminated wheat incorporated into diets of broiler chicks. Avian Dis. 41, 957-963.

Hedman, R., Pettersson, H., Engstrom, B., Elwinger, K., Fossum, O., 1995. Effects of nivalenol-contaminated diets to male broiler chickens. Poult. Sci. 74, 620-625.

Hedman, R., Pettersson, H., Lindberg, J.E., 1997. Absorption and metabolism of nivalenol in pigs. Arch. Anim. Nutr. 50, 13-24.

Hoehler, D., Marquardt, R.R., 1996. Influence of vitamins E and C on the toxic effects of ochratoxin A and T-2 toxin in chicks. Poult. Sci. 75, 1508-1515.

Ingalls, J.R., 1996. Influence of deoxynivalenol on feed consumption by dairy cows. Anim. Feed Sci. Technol. 60, 297-300.

Ito, Y., Ohtsubo, K.I., 1994. Effects of neonatal administration of zearalenone on the reproductive physiology of female mice. J. Vet. Med. Sci. 56, 1155-1159.

Javed, T., Richard, J.L., Bennett, G.A., Dombrink-Kurtzman, M.A., Bunte, R.M., Koelkebeck, K.W., Cote, L.M., Leeper, R.W., Buck, W.B., 1993a. Embryopathic and embryocidal effects of purified fumonisin $\mathrm{B}_{1}$ or Fusarium proliferatum culture material extract on chicken embryos. Mycopathologia 123, 185-193.

Javed, T., Bennett, G.A., Richard, J.L., Dombrink-Kurtzman, M.A., Cote, L.M., Buck, W.B., 1993b. Mortality in broiler chicks on feed amended with Fusarium proliferatum culture material or with purified fumonisin $\mathrm{B}_{1}$ and moniliformin. Mycopathologia 123, 171-184.

Kaliamurthy, P., Geraldine, P., Thomas, P.A., 1997. Effects of zearalenone on food consumption, growth, organ weight and serum testosterone level in male rats. J. Env. Biol. 18, 115-120.

Keshavarz, K., 1993. Corn contaminated with deoxynivalenol: effects on performance of poultry. J. Appl. Poult. Res. 2, 43-50.

Kidd, M.T., Qureshi, M.A., Hagler, W.M., Ali, R., 1997. T-2 tetraol is cytotoxic to a chicken macrophage line. Poult. Sci. 76, 311-313.

Kollarczik, B., Gareis, M., Hanelt, M., 1994. In vitro transformation of the Fusarium mycotoxins deoxynivalenol and zearalenone by the normal gut microflora of pigs. Nat. Toxins 2, 105-110. 
Kramer, R., Keogh, R.G., Sprosen, J.M., McDonald, M.F., 1997. Free and conjugated levels of zearalenone in ewes mated on grass-dominant pasture or chicory. Proc. N. Z. Soc. Anim. Prod. 57(90), .

Kubena, L.F., Edrington, T.S., Kamps-Holtzapple, C., Harvey, R.B., Elissalde, M.H., Rottinghaus, G.E., 1995. Influence of fumonisin $\mathrm{B}_{1}$ present in Fusarium moniliforme culture material, and $\mathrm{T}-2$ toxin on turkey poults. Poult. Sci. 74, 306-313.

Kubena, L.F., Edrington, T.S., Harvey, R.B., Buckley, S.A., Phillips, T.D., Rottinghaus, G.E., Caspers, H.H., 1997a. Individual and combined effects of fumonisin $\mathrm{B}_{1}$ present in Fusarium moniliforme culture material and T-2 toxin or deoxynivalenol in broiler chicks. Poult. Sci. 76, 1239-1247.

Kubena, L.F., Edrington, T.S., Harvey, R.B., Phillips, T.D., Sarr, A.B., Rottinghaus, G.E., 1997b. Individual and combined effects of fumonisin $\mathrm{B}_{1}$ present in Fusarium moniliforme culture material and diacetoxyscirpenol or ochratoxin A in turkey poults. Poult. Sci. 76, 256-264.

Lebepe-Mazur, S., Bal, H., Hopmans, E., Murphy, P., Hendrich, S., 1995. Fumonisin $B_{1}$ is fetotoxic in rats. Vet. Human Toxicol. 37, 126-130.

Ledoux, D.R., Bermudez, A.J., Rottinghaus, G.E., Broomhead, J., Bennett, G.A., 1995. Effects of feeding Fusarium fujikuroi culture material, containing known levels of moniliformin, in young broiler chicks. Poult. Sci. 74, 297-305.

Leeson, S., Diaz, G., Summers, J.D., 1995. Poultry Metabolic Disorders and Mycotoxins. University Books, Guelph, Canada, pp. 202-204.

Lusky, K., Tesch, D., Haider, W., 1997. Simultaneous administration of the mycotoxins ochratoxin A and Zearalenone to pigs in the feed. Effect on health and tissue residues. Tierarztl. Umsch. 52, 212-216.

Marasas, W.F.O., 1995. Fumonisins: their implications for human and animal health. Nat. Toxins 3, $193-198$.

Miles, C.O., Erasmuson, A.F., Wilkins, A.L., 1996. Ovine metabolism of zearalenone to $\alpha$-zearalanol (zeranol). J. Agric. Food Chem. 44, 3244-3250.

Neiger, R.D., Johnson, T.J., Hurley, D.J., Higgins, K.F., Rottinghaus, G.E., Stahr, H., 1994. The short-term effect of low concentrations of dietary aflatoxin and T-2 toxin on mallard ducklings. Avian Dis. 4, 738-743.

Osweiler, G.D., Kehrli, M.E., Stabel, J.R., Thurston, J.R., Ross, P.F., Wilson, T.M., 1993. Effects of fumonisincontaminated corn screenings on growth and health of feeder calves. J. Anim. Sci. 71, 459-466.

Overnes, G., Matre, T., Sivertsen, T., Larsen, H.J.S., Langseth, W., Reitan, L.J., Jansen, J.H., 1997. Effects of diets with graded levels of naturally deoxynivalenol-contaminated oats on immune response in growing pigs. J. Vet. Med. Series A 44, 539-550.

Placinta, C.M., D’Mello, J.P.F., Macdonald, A.M.C., 1999. A review of worldwide contamination of cereal grains and animal feed with Fusarium mycotoxins. Anim. Feed Sci. Technol. 78, 21-37.

Pfohl-Leszkowicz, A., Chekir-Ghedira, L., Bacha, H., 1995. Genotoxicity of zearalenone, an estrogenic mycotoxin: DNA adduct formation in female mouse tissues, Carcinogenesis 2315-2320.

Prathapkumar, S.H., Rao, V.S., Paramkishan, R.J., Bhat, R.V., 1997. Disease outbreak in laying hens arising from the consumption of fumonisin-contaminated food. Br. Poult. Sci. 38, 475-479.

Prelusky, D.B., 1997. Effect of intraperitoneal infusion of deoxynivalenol on feed consumption and weight gain in the pig. Nat. Toxins 5, 121-125.

Prelusky, D.B., Trenholm, H.L., Hamilton, R.M.G., Miller, J.D., 1987. Transmission of $\left[{ }^{14}\right.$ C] deoxynivalenol to eggs following oral administration to laying hens. J. Agric. Food Chem. 35, 182-186.

Prelusky, D.B., Rotter, B.A., Rotter, R.G., 1994a. Toxicology of mycotoxins. In: Miller, J.D., Trenholm, H.L. (Eds.), Mycotoxins in Grain, Compounds Other Than Aflatoxin, Eagen Press, St. Paul, pp. 359-403.

Prelusky, D.B., Gerdes, R.G., Underhill, L.K., Rotter, B.A., Jui, P.Y., Trenholm, H.L., 1994b. Effects of lowlevel dietary deoxynivalenol on haematological and clinical parameters of the pig. Nat. Toxins 2, 97-104.

Rafai, P., Bata, A., Vanyi, A., Papp, Z., Brydl, E., Jakab, L., Tuboly, S., Tury, E., 1995a. Effect of various levels of T-2 toxin on the clinical status, performance and metabolism of growing pigs. Vet. Rec. 136, 485-489.

Rafai, P., Tuboly, S., Bata, A., Tilly, P., Vanyi, A., Papp, Z., Jakab, L., Tury, E., 1995b. Effect of various levels of T-2 toxin in the immune system of growing pigs. Vet. Rec. 136, 511-514.

Reams, R., Thacker, H.L., Harrington, D., Vesonder, R., 1996. Development of an L6 myoblast in vitro model of moniliformin toxicosis. Mycopathologia 133, 105-114.

Richard, J.L., Meerdink, G., Maragos, C.M., Tumbleson, M., Bordson, G., Rice, L.G., Ross, P.F., 1996. Absence of detectable fumonisins in the milk of cows fed Fusarium proliferatum (Matsushima) Nirenberg culture material. Mycopathologia 133, 123-126. 
Richardson, K.E., Hagler, W.M., Mirocha, C.J., 1985. Production of zearalenone, $\alpha$ - and $\beta$-zearalanol by Fusarium spp. in rice culture. J. Agric. Food Chem. 33, 862-866.

Rotter, B.A., Thompson, B.K., Clarkin, S., Owen, T.C., 1993. Rapid colorimetric bioassay for screening of Fusarium mycotoxins. Nat. Toxins 1, 303-307.

Rotter, B.A., Thompson, B.K., Lessard, M., 1995. Effects of deoxynivalenol-contaminated diet on performance and blood parameters in growing swine. Can. J. Anim. Sci. 75, 297-302.

Rotter, B.A., Thompson, B.K., Prelusky, D.B., Trenholm, H.L., Stewart, B., Miller, J.D., Savard, M.E., 1996. Response of growing swine to dietary exposure to pure fumonisin $\mathrm{B}_{1}$ during an eight-week period: growth and clinical parameters. Nat. Toxins 4, 42-50.

Rotter, B.A., Prelusky, D.B., Fortin, A., Miller, J.D., Savard, M.E., 1997. Impact of pure fumonisin B ${ }_{1}$ on various metabolic parameters and carcass quality of growing-finishing swine-preliminary findings. Can. J. Anim. Sci. 77, 465-470.

Schumacher, J., Mullen, J., Shelby, R., Lenz, S., Ruffin, D.C., Kemppainen, B.W., 1995. An investigation of the role of Fusarium moniliforme in duodenitis/proximal jejunitis of horses. Vet. Human. Toxicol. 37, 39-45.

Smith, T.K., McMillan, E.G., Castillo, J.B., 1997. Effect of feeding blends of Fusarium mycotoxin-contaminated grains containing deoxynivalenol and fusaric acid on growth and feed consumption of immature swine. J. Anim. Sci. 75, 2184-2191.

Smith, G.W., Constable, P.D., Smith, A.R., Bacon, C.W., Meredith, F.I., Wollenberg, G.K., Haschek, W.M., 1996a. Effects of fumonisin-containing culture material on pulmonary clearance in swine. Am. J. Vet. Res. 57, 1233-1238.

Smith, G.W., Constable, P.D., Bacon, C.W., Meredith, F.I., Haschek, W.M., 1996b. Cardiovascular effects of fumonisins in swine. Fund. Appl. Toxicol. 31, 169-172.

Towers, N.R., Sprosen, J.M., 1993. Zearalenone-induced infertility in sheep and cattle in New Zealand. N. Z. Vet. J. 41, 223-224.

Trenholm, H.L., Foster, B.C., Charmley, L.L., Thompson, B.K., Hartin, K.E., Coppock, R.W., Albassam, M.A., 1994. Effects of feeding diets containing Fusarium (naturally) contaminated wheat or pure deoxynivalenol (DON) in growing pigs. Can. J. Anim. Sci. 74, 361-369.

Trucksess, M.W., Thomas, F., Young, K., Stack, M.E., Fulgueras, W.J., Page, S.W., 1995. Survey of deoxynivalenol in US. 1993 wheat and barley crops by enzyme-linked immunosorbent assay. J. A.O.A.C. Int. 78, 631-636.

Trucksess, M.W., 1997. Mycotoxins. J. A.O.A.C. Int. 80, 119-126.

Vanyi, A., Bata, A., Kovacs, F., 1994a. Effects of T-2 toxin treatment on egg yield and hatchability in geese. Acta Vet. Hung. 42, 79-85.

Vanyi, A., Glavits, R., Bata, A., Kovacs, F., 1994b. Pathomorphological changes caused by T-2 trichothecene fusariotoxin in geese. Acta Vet. Hung. 42, 447-457.

Vanyi, A., Bata, A., Glavits, R., Kovacs, F., 1994c. Perinatal oestrogen syndrome in swine. Acta Vet. Hung. 42, 433-446.

Vesonder, R.F., Wu, W., 1998. Correlation of moniliformin, but not fumonisin B1 levels, in culture materials of Fusarium isolates to acute death in ducklings. Poult. Sci. 77, 67-72.

Weaver, G.A., Kurtz, H.J., Behrens, J.C., Robison, T.S., Seguin, B.E., Bates, F.Y., Mirocha, C.J., 1986. Effect of zearalenone on the fertility of virgin dairy heifers. Am. J. Vet. Res. 47, 1395-1397.

Williams, K.C., Blaney, B.J., 1994. Effect of the mycotoxins, nivalenol and zearalenone, in maize naturally infected with Fusarium graminearum on the performance of growing and pregnant pigs. Aust. J. Agric. Res. 45, 1265-1279.

Yamini, B., Bursian, S.J., Aulerich, R.J., 1997. Pathological effects of dietary zearalenone and/or tamoxifen on female mink reproductive organs. Vet. Human Toxicol. 39, 74-78.

Yoo, H.S., Norred, W.P., Showker, J., Riley, R.T., 1996. Elevated sphingoid bases and complex sphingolipid depletion as contributing factors in fumonisin-induced cytotoxicity. Toxicol. Appl. Pharmacol. 138, 211218.

Yoshizawa, T., 1991. Natural occurrence of mycotoxins in small grain cereals (wheat, barley, rye, oats, sorghum, millet, rice). In: Smith, J.E., Henderson, R.S. (Eds.), Mycotoxins and Animal foods. CRC Press, Boca Raton, pp. 301-324. 
Zacharias, C., Echten-Deckert, G.V., Wang, E., Merrill, A.H., Sandhoff, K., 1996. The effect of fumonisin B1 on developing chick embryos: correlation between de novo sphingolipid biosynthesis and gross morphological changes. Glycoconjugate J. 13, 167-175.

Zomborszky, M.K., Vetesi, F., Repa, I., Horn, P., Kovacs, F., 1997a. Effects of toxins produced by Fusarium moniliforme on pigs. I. Definition of tolerance limit values in weaned piglets. Magy. Allatorv. Lap. 119, 759762.

Zomborszky, M.K., Vetesi, F., Horn, P., Kovacs, F., 1997b. Effects of toxin produced by Fusarium moniliforme on pigs II. Perinatal toxicity in pregnant sows and newborn piglets. Preliminary communication. Magy. Allatorv. Lap. 119, 763-764. 